\title{
Problem powstania i charakteru prawa małżeńskiego z 1836 roku
}

W XIX w. na ziemiach polskich doszło do zasadniczych zmian w przedmiocie regulacji małżeństwa. Wprowadzenie Kodeksu Napoleona w Księstwie Warszawskim doprowadziło do całkowitej sekularyzacji tej instytucji. Zastąpienie francuskich przepisów kodeksem cywilnym uchwalonym w $1825 \mathrm{r}$. przez sejm Królestwa Kongresowego przywróciło małżeństwu wymiar religijny. Zmianom tym towarzyszyły spory natury ideologicznej o kształt państwowego ustawodawstwa małżeńskiego. Kwestia określenia prawnego kształtu małżeństwa w polskim prawie ujawniła się następnie po odzyskaniu niepodległości, wywołując emocje nie mniejsze od tych, które pojawiły się w parlamentarnym okresie Polski Kongresowej.

Prawo małżeńskie było przedmiotem wielu kontrowersji. Dochodziło na jego tle do ścierania się dwóch doktryn: indywidualistycznej, zasadzającej się na prawie rzymskim, określającej małżeństwo jako związek wolny (rozwiązywalny), pozbawiony zabarwień religijnych, oraz wyznaniowej, opartej na myśli chrześcijańskiej, głównie katolickiej, przypisującej małżeństwu szczególne znaczenie religijne (małżeństwo sakramentalne). W XIX w. rozstrzygnięciem tego sporu było poniekąd wejście w życie dekretu Mikołaja I o małżeństwie w 1836 r. Natomiast po odzyskaniu niepodległości kwestii spornych nie rozstrzygnięto. W II Rzeczypospolitej nie doszło bowiem do unifikacji prawa małżeńskiego. Przyczyną była postawa Kościoła rzymskokatolickiego, który zwalczał projekt przygotowany przez Komisję Kodyfikacyjną w 1929 r. Projekt ten nigdy nie stał się obowiązującym prawem. Natomiast niektóre jego rozwiązania pojawily się $\mathrm{w}$ prawie polskim w $1998 \mathrm{r}$. W rezultacie dekret z 1836 r. pozostał w mocy do końca 1945 r. Paradoksalnie więc, o ile w XIX wieku konflikt o prawne oblicze małżeństwa zakończył się wejściem w życie dekretu z 1836 r., o tyle w II Rzeczypospolitej doprowadził do utrzymania tego dekretu w mocy. Carskie prawo okazało się wyjątkowo odporne na zapędy reformatorów, zarówno z prawej, jak i lewej strony.

Dopiero zmiana stosunków politycznych po 1945 r. oraz związane z tym obniżenie pozycji politycznej Kościoła rzymskokatolickiego umożliwiło unifi- 
kację prawa małżeńskiego w duchu zasady świeckości. Prawo małżeńskie z 1945 r. przecięło spory ideologiczne w XX w., podobnie jak prawo małżeńskie z 1836 r. przecięło te spory w wieku XIX. Różnica polegała jedynie na kierunku, w którym rozstrzygnięcie to nastapiło. O ile bowiem w XIX w. skończyło się na wprowadzeniu ustawodawstwa o mieszanym cywilno-religijnym obliczu, o tyle po wyzwoleniu rozstrzygnięcie polegało na definitywnym zerwaniu z koncepcją religijną małżeństwa w prawie państwowym. Rozwiązanie to, odpowiadające w istocie koncepcji małżeństwa przyjętej w Księstwie Warszawskim wraz z wprowadzeniem Kodeksu Napoleona, nie budziło istotnych wattpliwości w Polsce Ludowej. Po wyzwoleniu w 1945 r. nie postulowano z reguły wprowadzania do systemu państwowego prawa małżeńskiego elementów wyznaniowych. Wówczas bowiem nie brano w ogóle pod uwagę powrotu koncepcji dychotomicznego, świecko-wyznaniowego ustawodawstwa małżeńskiego w Polsce. Obecnie jednak lansuje się takie koncepcje, a część z nich już zrealizowano. Pozostałe zamysły zatrzymały się na razie na etapie postulatów ${ }^{1}$.

Prawo o małżeństwie z $1836 \mathrm{r}$. zostało wprowadzone na obszarze Królestwa Kongresowego przez cara Mikołaja I i obowiązywało do końca roku 1945. Było zatem jednym z najdłużej obowiązujących ustawodawstw małżeńskich na ziemiach polskich. Kulisy powstania tego prawa wiążą się ze sporami o kształt prawny małżeństwa w Królestwie Kongresowym. Na jego obszarze obowiązywał wzbudzający niechęć części społeczeństwa, wprowadzony w 1808 r., Kodeks Napoleona. Traktował on małżeństwo jako instytucję na wskroś świecką, wyzutą z pierwiastków religijnych (umowa cywilna). Jurysdykcję matrymonialną powierzał sądom państwowym.

Unormowania Kodeksu Napoleona, będące wyrazem liberalnej i antyklerykalnej myśli Rewolucji Francuskiej, miały ponoć prowadzić do upadku moralnego społeczeństwa. Toteż już w 1818 r. na pierwszym sejmie Polski Kongresowej podjęto próbę uchylenia przepisów o małżeństwie. Projekt przewidywał przywrócenie religijnej formy zawarcia małżeństwa, przy jednoczesnym utrzymaniu świeckiej jurysdykcji matrymonialnej. Na to rozwiązanie umiarkowana część posłów przystać nie mogła. Natomiast prokatolicka część sejmu domagała się, oprócz zniesienia rozwodów i cywilnej formy zawarcia małżeństwa, przekazania jurysdykcji matrymonialnej sądom duchownym. W rezultacie projekt został odrzucony wspólnymi głosami posłów liberalnych (dla których był zbyt katolicki) i posłów ultrakatolickich (dla których był za mało katolicki) ${ }^{2}$.

${ }^{1}$ Niepowodzeniem zakończyła się próba przywrócenia jurysdykcji cywilnej katolickich sądów kościelnych, podjęta w ramach projektu konkordatu przekazanego przez nuncjusza abp. Kowalczyka rządowi polskiemu w $1991 \mathrm{r}$.

${ }^{2}$ Por. H. Konic, Dzieje prawa matżeńskiego w Królestwie Kongresowym, Warszawa 1903, oraz rec. tejże pracy pióra Józefa Brzezińskiego, „Czasopismo Prawne i Ekonomiczne” (V) 1904, s. 229 i nast. 
Sejm zajął się ponownie problematyką małżeńską w 1825 r. Wówczas uchylono przepisy o małżeństwie Kodeksu Napoleona i zastapiono je rodzimym kodeksem cywilnym. Nowa regulacja małżeństwa nie była wyrazem kompromisu. Niemniej, pomimo sprzeciwu kleru katolickiego, car - aby uniknać utrzymania w mocy dotychczasowego prawa - zgodził się na pozostawienie spraw małżeńskich w gestii sądów cywilnych ${ }^{3}$. Wchodzący w życie z dniem 1 stycznia 1826 r. kodeks ustanawiał więc, jako obligatoryjna, wyznaniową formę zawarcia małżeństwa, ale zarazem utrzymywał przy sądach powszechnych jurysdykcję matrymonialną. Zasadniczym problemem stał się, dotyczący tej kwestii, art. 249. Stanowił on, że nieważność, rozwiązanie i rozłączenie małżeństwa może dokonać się mocą orzeczenia sądu cywilnego, ale na zasadzie ustaw religijnych małżonków. To rozstrzygnięcie doprowadziło do bojkotu nowego ustawodawstwa małżeńskiego przez kler katolicki. Duchowni katoliccy odmawiali respektowania orzeczeń sądów powszechnych unieważniających małżeństwa katolickie. Małżonkowie tacy byli wprawdzie stanu „wolnego”, ale nie mogli zawrzeć ponownych związków w Kościele katolickim, ponieważ duchowni katoliccy odmawiali asystowania przy ich zawieraniu.

Próbę uzdrowienia zaistniałego stanu rzeczy podjęto na sejmie w $1830 \mathrm{r}$., ale podobnie jak w 1825 r. nie zdołano zebrać większości sejmowej, która byłaby zdolna przekazać jurysdykcję matrymonialną sądom duchownym. Przez cały bowiem okres „konstytucyjnego” Królestwa Kongresowego istniała w sejmie większość, która skłonna była ostatecznie zaakceptować zniesienie obligatoryjnych małżeństw cywilnych, ale w żadnym wypadku nie godziła się na uchylenie państwowej jurysdykcji matrymonialnej. W każdej z trzech prób podważenia tejże jurysdykcji na sejmach 1818, 1825 i $1830 \mathrm{r}$. większość ta skutecznie temu zapobiegła. Rozwiązania kompromisowe, które umniejszały znaczenie orzeczeń sądów powszechnych w sprawach małżeńskich, były odrzucane przez sejm. Tak też uczynił ostatni sejm Królestwa Kongresowego w czerwcu 1830 r., nie uwzględniając jednocześnie zaleceń dworu petersburskiego. Po tej klęsce obozu katolickiego car wydał radzie administracyjnej polecenie opracowania projektu postanowienia, które zapobiegałoby kolizji władzy duchownej i państwowej. Projekt ów, zatwierdzony przez radę administracyjną w dniu 10 lipca 1830 r., sprowadzał się do przyznania biskupom prawa weryfikowania orzeczeń sądów powszechnych, toteż rychło zyskał poparcie całej hierarchii katolickiej. Także w lipcu 1830 r. rada administracyjna wespół z biskupami ułożyła zbiór postanowień prawa kanonicznego, dotyczących małżeństwa. Compendium to zostało następnie wprowadzone do prawa z $1836 \mathrm{r}$. Działania powyższe przerwał wybuch powstania listopadowego.

${ }^{3}$ H. Konic, Dzieje..., s. 38. 
Po jego upadku zniesiono konstytucję z 1815 r., a wydany w 1832 r. statut organiczny całą władzę ustawodawczą przyznał carowi, choć utrzymał jednocześnie autonomię Królestwa Kongresowego. W Radzie Państwa w Petersburgu utworzono jednakże departament interesów Królestwa Polskiego, tam też przeniósł się punkt ciężkości zarządu Królestwem. Decyzje tegoż departamentu o zwróceniu władzy duchownej spraw małżeńskich katolików car zatwierdził w 1833 r. Departament opracował również zasady, którym odpowiadać miał przyszły projekt prawa małżeńskiego. Sprawy separacyjne i o uznanie nieważności małżeństwa katolickiego poddano władzy duchownej, zaś orzekanie o skutkach cywilnych rozwiedzionych małżeństw przyznano sądom powszech$n^{n}{ }^{4}$. Przygotowanie projektu powierzono komisji sprawiedliwości w Warszawie. Według S. Tylbora projekt ten obejmował tylko niektóre materie oraz zachował nienaruszone zasady obowiązującego prawa małżeńskiego, zmieniając wyłącznie formalne przepisy tego prawa w duchu bulli Benedykta XIV Dei miseratione $^{5}$. Został on przedstawiony do zatwierdzenia radzie administracyjnej w dniu 22 maja 1834 r., a następnie przesłany do Petersburga. Tam zajął się nim Departament do spraw Królestwa Polskiego. W Petersburgu działała komisja przygotowawcza do rewizji i ułożenia praw Królestwa Polskiego. Autorem osobnego projektu prawa małżeńskiego tej komisji był Cyprjan Zaborowski. W Petersburgu stworzono nowy projekt, który zdaniem H. Konica był kompilacją projektów: warszawskiego i Zaborowskiego ${ }^{6}$. H. Konic zaznaczył, że Zaborowski był autorem projektu wypracowanego przez komisję przygotowawcza, lecz z tego nie wynika, aby prawo z $1836 \mathrm{r}$. było jego dziełem, gdyż do takiego wniosku nie upoważniają źródła ${ }^{7}$. S. Holewiński uważał jednak, że podstawę przyszłego prawa stanowił wyłącznie projekt Zaborowskiego ${ }^{8}$. Również S. Tylbor przywiązywał do niego dużą wagę. Jego zdaniem, Cyprjan Zaborowski chciał oprzeć się na Statucie litewskim. Ostatecznie jednak projekt prawa małżeńskiego zbliżono do Zwodu Praw Cesarstwa Rosyjskiego. „Gdy zdecydowano się - wyjaśniał Tylbor - pomieścić w prawie odrębne przepisy dla każdego

\footnotetext{
${ }^{4}$ H. Konic, Prawo matżeńskie obowiazujace w b. Królestwie Kongresowym, Warszawa 1924, s. 47

${ }^{5}$ S. Tylbor, Próby reformy Kodeksu Cywilnego, Warszawa 1927, s. 15.

${ }^{6}$ H. Konic, Prawo matżeńskie..., s. 48.

${ }^{7}$ Idem, Dzieje..., s. 108.

${ }^{8}$ S. Holewiński, W setna rocznicę prawa małżeńskiego, Odbitka z Nr 12 i 13 GSW, 1936, s. 12 i n., podaje, że w Petersburgu nie doszło do kompilacji projektów: warszawskiego i Zaborowskiego. Pierwszy z nich został po prostu odrzucony przez Departament, toteż prawo małżeńskie z $1836 \mathrm{r}$. oparte jest wyłącznie na ,projekcie Zaborowskiego”, opracowanym w komisji, w której przewodniczył Sperański. Projekt ten, przygotowany w języku francuskim, został następnie przetłumaczony na język rosyjski i po naniesieniu niewielkich zmian wprowadzony w życie. „Projekt Zaborowskiego” rozszerzył wyznaniową jurysdykcję matrymonialną. Objął nią wyznania: rzymskokatolickie, grecko-rosyjskie, grecko-unickie, ewangelicko-augsburskie, ewangelicko-reformowane oraz małżeństwa mieszane tych wyznan. Natomiast projekt warszawski przewidywał ją tylko w dwóch wyznaniach: rzymskokatolickim i prawosławnym.
} 
wyznania, podobieństwo do Zwodu wystąiło wyraziście". Decydujący wpływ na ostateczny kształt projektu C. Zaborowskiego miał A. Sperański, który dokonał w nim szeregu zmian, w tym wyodrębnienia osobnego rozdziału poświęconego małżeństwom grecko-unickim. Następnie zrezygnowano z nieznanych Zwodowi przepisów o międzynarodowym prawie małżeńskim oraz zmieniono przepisy o małżeństwach mieszanych ${ }^{9}$.

Utrata w okresie okupacji źródeł dostępnych badaczom międzywojennym uniemożliwia rozstrzygnięcie wątpliwości związanych z przebiegiem tworzenia prawa małżeńskiego ${ }^{10}$. W szczególności nie jest możliwe usunięcie niejasności w przedmiocie roli czynnika warszawskiego w procesie legislacyjnym, a mianowicie: czy projekt warszawski został wzięty pod uwagę w Petersburgu, a w konsekwencji, czy wpłynął on na ostateczny kształt nowego prawa? Różnica zdań pomiędzy Konicem i Holewińskim w tej kwestii stanowi poważny problem. Niestety kwestia ta w oparciu o dostępne w kraju źródła nie wydaje się możliwa do wyjaśnienia.

Jednym z kluczowych zagadnień związanych z nowym prawem małżeńskim była, szeroko komentowana po odzyskaniu niepodległości, pozycja Kościoła prawosławnego w Królestwie Kongresowym. Kwestia ta stała się przedmiotem dekretu carskiego z 8 III 1825 r. oraz związanego z nim ukazu do Synodu petersburskiego z 15 XI 1827 r. Podporządkowano w nim parafie prawosławne biskupowi wołyńskiemu oraz polecono wysłanie delegata duchownego w celu negocjacji z rządem Królestwa Kongresowego. E. Sakowicz podaje, że carowi chodziło o rozgraniczenie kompetencji sądu biskupiego i władz świeckich, działających na podstawie praw Królestwa. Przedmiotem żądań Synodu były między innymi sprawy rozwodowe. Komisja Wyznań nie przyjęła tych żądań, ale ostateczną decyzję miał podjąć car. Skutkiem negocjacji był układ zawarty w 1828 r. pomiędzy Komisją Rządową W. R. i O. P. a delegatem Synodu mogący, zdaniem księcia F.K. Lubeckiego, prowadzić do zmiany polskiego ustawodawstwa ${ }^{11}$.

Po upadku powstania listopadowego kwestia ta odżyła. Przy tworzeniu prawa z 1836 r. chciano stworzyć przewagę Kościoła katolickiego nad prawosławnym - nie zgodził się jednak na to carr $^{12}$. Mikołaj I nakazał wprowadzić zmiany do przedstawionego mu projektu, których skutkiem było uszczuplenie jurysdykcji Kościoła katolickiego ${ }^{13}$. Nad tym faktem boleje zwłaszcza

${ }^{9}$ S. Tylbor, Próby reformy..., s. 14.

${ }^{10} \mathrm{Na}$ ten temat szerzej zob. A. Stebelski, Straty Archiwów i Bibliotek Warszawskich w zakresie rękopiśmiennych źródet historycznych, Warszawa 1957.

${ }^{11}$ E. Sakowicz, Polscy mężowie stanu o Statucie Kościoła Prawosławnego w Królestwie Kongresowym. „Wiadomości Metropolii Prawosławnej w Polsce” z dn. 16 IV 1939 r. Nr 16, s. 4.

${ }^{12}$ H. Konic, K. Lutostański, Prawo cywilne obow. w b. Król. Polskiem. Repetytorium egzaminacyjne, s. 59.

${ }^{13} \mathrm{~S}$. Holewiński, W setna rocznice prawa matżeńskiego, Odbitka z Nr 12 i 13 GSW, 1936. s. 17-18, podaje że, komisja Sperańskiego rozróżniła małżeństwa osób wyznania prawosławnego, 
J. Brzeziński, pisząc, że art. 200-204, odnoszące się do małżeństw katolików z osobami wyznania prawosławnego, są wprost sprzeczne z zasadami Kościoła katolickiego i jego prawami ${ }^{14}$. Z kolei Holewiński uznaje te przepisy za przejaw tendencji rusyfikacyjnych ${ }^{15}$. Dopiero po tych zmianach projekt uzyskał aprobatę władcy - 16/28 marca 1836 r. ukazał się dekret cesarski wprowadzający Prawo o małżeństwie. Jego ogłoszenie nastąpiło w dniu 24 czerwca 1836 r. (Dz. Praw Tom XVIII, s. 57-297).

Nowe prawo składało się z XI rozdziałów, które poprzedzała preambuła, zawierająca ogólne wyjaśnienia ustawodawcy co do kształtu przyjętych rozwiązań ustawowych. Regulacja obejmowała w szczególności zagadnienia dotyczące osobowego prawa małżeńskiego. Majątkowe prawo małżeńskie znajdujące się w kodeksie z 1825 r. zostało utrzymane w mocy przez art. $248 \mathrm{PM}^{16}$.

Zasadniczy element nowego prawa stanowiły przepisy międzywyznaniowe, zamieszczone w rozdziale VI. Przepisy te regulowały kwestię właściwości sądu duchownego w sprawie małżeńskiej. W grę wchodziła właściwość sądu tylko tego wyznania, któremu nowe prawo przyznało jurysdykcję w sprawach małżeńskich. Jurysdykcję tę otrzymało tylko pięć wyznań: rzymskokatolickie, prawosławne, grecko-katolickie, ewangelicko-augsburskie i ewangelicko-reformowane. Odnośnie do członków pozostałych wyznań orzekały sądy cywilne. Sądy kościelne, w granicach określonych w przepisach międzywyznaniowych, posiadały jurysdykcję cywilną. W pozostałym zakresie sądy te orzekały w oparciu o jurysdykcję wynikającą z przepisów prawa kościelnego, a ich orzeczenia nie wywierały skutków cywilnych.

Prawo małżeńskie przewidywało odrębne przepisy dla członków wyznań, które uzyskały jurysdykcję w sprawach małżeńskich. Zostały one zamieszczone w osobnych rozdziałach, z których każdy poświęcono jednemu z kilku

zapisanych do ksiag stałej ludności Królestwa przed 14/26 II 1832 r. od małżeństw osób tego wyznania później osiadłych w Królestwie. Małżeństwa pierwszego typu zawierane miały być w świątyni wyznania narzeczonej. Gdy narzeczona nie była prawosławna, błogosławieństwa musiał udzielić również duchowny prawosławny. Właściwym w sprawie ważności związku był sąd duchowny tego wyznania, którego duchowny dawał ślub. Synowie przyjmowali religię ojca, a córki matki. W przypadku drugiego typu, ślubu mógł udzielić wyłącznie duchowny prawosławny, a sądy tego wyznania były wyłącznie właściwe w przedmiocie ważności i rozwiązania małżeństwa. Dzieci zrodzone z tych związków musiały być wychowywane w wierze prawosławnej. Za sprawą carskiej decyzji z rozróżnienia powyższego zrezygnowano, a obowiązującym prawem stało się rozwiązanie przewidziane dla drugiej grupy; wobec wszystkich związków z prawosławnymi, właściwym był konsystorz prawosławny.

${ }^{14}$ Zob. rec. Józefa Brzezińskiego, „Czasopismo Prawne i Ekonomiczne”(V) 1904, s. 229 i nast.

${ }^{15} \mathrm{~S}$. Holewiński, $W$ setna rocznicę..., s. 12 i nast.

${ }^{16}$ Art. 248 PM stanowił: „Z dniem ogłoszenia ninieyszego prawa, przestają obowiązywać tytuły V i VI prawa cywilnego Królestwa Polskiego, z dnia 1/13 czerwca 1825 roku, z wyłączeniem art. 182 i następnych, aż do art. 245 włącznie, tudzież art. 260 i następnych, aż do art. 270 włącznie. Artykuły pomienione, iako ściagaiące się do przedmiotów prawem ninieyszem nieurządzonych, a mianowicie do stosunków maiątkowych między małżonkami, utrzymuią się nadal w swey mocy". 
wzmiankowanych wyznań. Odnośnie do pozostałych wyznań ustawa zawierała odesłanie do wewnętrznych regulacji związków wyznaniowych (art. 179 PM). Rozwiązanie to prowadziło do niejednolitości prawa małżeńskiego. Konsekwencją przyjętej metody regulacji były między innymi odrębne dla każdego wyznania materialne przesłanki rozwiązania małżeństwa. W ramach przesłanek procesowych ustawodawca podjął, tylko częściowo udaną, próbę bezkolizyjnego uregulowania małżeńskich stosunków międzywyznaniowych. W tym stanie rzeczy instytucja rozwodu nabierała niejednolitego charakteru. Niejednolitość prawa materialnego, w powiązaniu z przepisami międzywyznaniowymi, stanowi $\mathrm{w}$ istocie zasadniczy element charakteryzujący prawo z $1836 \mathrm{r}$.

W II Rzeczypospolitej wątpliwości budził stosunek prawa mikołajewskiego do wewnętrznych ustaw kościelnych. Doktryna międzywojenna nie zajmowała w tej mierze jednoznacznego stanowiska. M. Allerhand pisał, że prawo religijne może być uznane za prawo państwowe $\mathrm{w}$ treści oryginalnej bądź w przeróbce:

„W tym przypadku prawo religijne dla władz państwowych przestaje być samoistnem i staje się państwowem i tylko jako takie winno być uważane, zaczem przy wykładni nie można się powoływać na zasady prawa religijnego, lecz uwzględnić wypada całokształt prawa państwowego. Prawo religijne recypowane przez prawo państwowe, ma w stosunku do tego tylko wartość historyczna...."17.

Jako przykład takiej recepcji M. Allerhand wskazuje ustawę cywilną austriacką z $1811 \mathrm{r}$. i przepisy rozdziału I prawa mikołajewskiego, dotyczącego małżeństw zawieranych przez osoby wyznania rzymskokatolickiego.

Czy jednak prawo z $1836 \mathrm{r}$. było całkowicie oderwane od swoich źródeł, tj. ustawodawstw poszczególnych Kościołów? Niektórzy komentatorzy uważali bowiem, iż powołanie się na przepisy religijne w prawie z $1836 \mathrm{r}$. oznacza, że niezależnie od ustawy państwowej obowiązują ustawy kościelne, uzupełniające lub korygujące jej postanowienia. Problem recepcji prawa religijnego w państwowym prawie małżeńskim miał zatem kluczowe znaczenie dla wykładni prawa.

Skutkiem niejasnego stosunku prawa małżeńskiego z 1836 r. do ustaw kościelnych były wątpliwości, czy konkretne orzeczenie sądu konsystorskiego opiera się na przepisach prawa małżeńskiego, czy tylko na regulacjach kościelnych, niemających potwierdzenia w ustawie państwowej. Sprawę dodatkowo komplikowały zmiany prawa kanonicznego. Wobec tego, zasadniczym problemem związanym z zaproponowaną w $1836 \mathrm{r}$. metodą normowania małżeństwa była kwestia wpływu zmiany pozaustawowego źródła prawa małżeńskiego na

${ }^{17}$ M. Allerhand, Stosunek prawa państwowego do prawa religijnego, „Głos Prawa” Nr 5-6/1927, s. 170 
państwową ustawę małżeńską. Czy zmiana taka pociagała za sobą zmianę państwowego prawa małżeńskiego? Jak wyjaśniał M. Allerhand,

„prawo państwowe zamiast ujmować zasady religijne w samoistne normy ustawowe, może się ograniczyć do powołania się na prawo religijne i postanowić tylko całkiem ogólnikowo, że to prawo rozstrzyga o stosunkach danego wyznania. $\mathrm{W}$ ten sposób postąpiło prawo o małżeństwie z roku 1836..., o ile rozchodzi się o małżeństwa osób wyznania grecko-rosyjskiego i wyznań niechrześcijańskich... W przypadku takiego unormowania prawo religijne staje się państwowem, ale rzecz ma się inaczej niż wtedy, gdy na podstawie prawa religijnego dokładnie normuje się pewne przepisy, bo za podstawę orzeczenia zawsze wziąć należy prawo religijne. Jeżeliby więc społeczność religijna zmieniła swoje prawo, to przepis zmieniony a nie dawny winien być uwzględniony i to bez badania, czy ze stanowiska wyznania zmiana była dopuszczalna, jeżeli tylko powołana do tego władza religijna zmianę przeprowadziła..."

W konsekwencji metoda ,powołania” sprawia, że obowiązujące w chwili orzekania prawo religijne znajduje zastosowanie w sferze stosunków państwowych. Staje się zatem podstawą rozstrzygnięć skutecznych nie tylko w stosunkach kościelnych, ale także względem państwa. Metodą tą posłużono się w art. 179 PM, który odsyła w przedmiocie zawarcia i rozwiązania małżeństwa niechrześcijańskiego do prawa religijnego. Podobne rozwiązanie zastosowano w art. 117 PM, który w sprawie przyczyn rozwodowych odsyła do prawosławnego prawa kanonicznego.

Poglądy międzywojennych komentatorów prawa mikołajewskiego nie były jednak zgodne co do zakresu zastosowania metody „powołania”. W przeciwieństwie do M. Allerhanda, S. Tylbor uznaje, że powyższy model regulacji małżeństwa został zrealizowany przez twórców dekretu mikołajewskiego w przypadku każdego wyznania. Oznaczało to, że

„ustawodawca z r. 1836 recypował, jako obowiązujące, przepisy religijne każdego wyznania, przez co każdoczesna zmiana tych przepisów winna być uważana za obowiązującą bez potrzeby specjalnego ogłoszenia jej w b. Królestwie”.

Wyjątek stanowić miały przepisy prawa cywilnego, którym ustawodawca nadał moc bezwzględnie obowiązująca, np. ustanawiając zasadę monogamiczności małżeństwa, która wyłączała wielożeństwo, dozwolone w wyznaniu mahometańskim (art. $181 \mathrm{PM})^{19}$.

Problem stanowiła kwestia znaczenia w stosunkach cywilnoprawnych, zamieszczonych w ustawie państwowej, katolickich przepisów kanonicznych.

${ }^{18}$ Ibidem, s. 171.

${ }^{19}$ S. Tylbor, Matżeńskie Prawo, [w:] Encyklopedia Prawa Prywatnego, pod red. Zolla-Wasilkowskiego. 
Jak M. Allerhand, S. Tylbor dostrzegał, że ustawa państwowa kompleksowo uregulowała małżeństwo katolickie. Stwierdził mianowicie:

„prawo małżeńskie zawiera mniej lub więcej wyczerpujące przepisy, regulujące pewne kwestje, dotyczące zawarcia i ustania małżeństwa zgodnie z ówcześnie, t.j. w r. 1836 obowiązującemi przepisami religijnymi danego wyznania, przyczem najściślej reguluje małżeństwa katolickie”.

Niemniej według poglądów tego autora, wprowadzenie katolickich przepisów kanonicznych do ustawy państwowej nie oznaczało pozbawienia mocy obowiązującej w stosunkach cywilnych pozostałych przepisów małżeńskiego prawa kanonicznego. Niezależnie więc, czy przepisy kanoniczne, regulujące poszczególne kwestie, znalazły się w ustawie państwowej, czy też nie, małżeńskie prawo kanoniczne obowiązywało w stosunkach cywilnoprawnych w pełnym zakresie.

Rozwiązanie to prowadziło do prymatu prawa religijnego w stosunkach państwowych. Przepisy prawa kanonicznego, zamieszczone w państwowej ustawie małżeńskiej, znajdowały zastosowanie jedynie w przypadku braku sprzeczności z przepisami prawa religijnego. S. Tylbor zaznaczał:

„Ponieważ każdoczesne prawo kanoniczne jest źródłem prawa małżeńskiego cywilnego, przeto, w razie różnic między niem a prawem małżeńskim z r. 1836, obowiązuje nie to ostatnie prawo, ale prawo kościelne, religijne, chyba że prawo o małżeństwie z r. 1836 wyraźnie nadaje pewnym swoim przepisom charakter normy bezwzględnie wiążącej”20.

Za przepisy bezwzględnie obowiązujące powszechnie uznawano przepisy międzywyznaniowe ustawy państwowej. Taki charakter nadawano także art. $48 \mathrm{PM}$, regulującemu formę zawarcia małżeństwa w wyznaniu rzymskokatolickim.

Powyższą formułę recepcji prawa religijnego poparł także R. Longchamps de Bérier. Niemniej, stanowisko tego autora nie było wolne od wątpliwości związanych z inkorporowaniem konkretnych postanowień prawa kanonicznego do ustawy państwowej. Obecność tych przepisów w ustawie państwowej sugerowała bowiem, że ustawodawca posłużył się przeciwną metodą ${ }^{21}$. Wów-

${ }^{20}$ Idem, Dzisiejsze prawo matżeńskie w b. Królestwie Kongresowym, odbitka z „Głosu Sądownictwa" nr 7-8 1939, s. 5-6. Tego samego zdania jest H. Konic, Prawo matżeńskie..., s. 63-65.

${ }^{21}$ R. Longchamps de Bérier, (w:) Matżeństwo w świetle nauki katolickiej, Lublin 1928, s. $343-$ -346, w swych rozważaniach zastanawia się nad problemem, „czy za obowiązujące uznano każdoczesne prawo kościelne danego wyznania, czy prawo obowiązujące wyznawców w chwili ogłoszenia prawa z r. 1836". Zdaniem autora nie byłoby wątpliwości, gdyby prawo z $1836 \mathrm{r}$. ograniczyło się do art. 2, 3, 73, 77, 98, 117, 124 i 179, a więc przepisów, które uznają bądź powołują się na wewnętrzne unormowania wyznaniowe. PM jednakże, „reprodukuje odnośne przepisy kościelne, skąd 
czas metoda regulacji przyjęta w dekrecie mikołajewskim opierałby się, jak słusznie zauważył R. Longchamps de Berier, na zasadzie inkorporacji praw religijnych do państwowego prawa małżeńskiego, zaś przepisy powołujące się na wewnętrzne prawa religijne utraciłyby sens. Wszelkie bowiem pozaustawowe źródła prawa małżeńskiego, przy takim modelu regulacji, nie mogą mieć mocy obowiązującej, gdyż mająjąjedynie normy wyznaniowe inkorporowane do prawa państwowego.

R. Longchamps de Bérier nie wskazał argumentu, który miałby przeważyć szalę na rzecz preferowanego przezeń modelu recepcji prawa religijnego. Być może decydujący był wzgląd na praktykę stosowania prawa. Nie wydaje się bowiem prawdopodobne, aby sądy duchowne katolickie nie przyjmowały za podstawę swoich orzeczeń aktualnego prawa kanonicznego.

Konsekwencją opowiedzenia się za modelem „powołania” było przyjęcie, że możliwe jest obowiązywanie w stosunkach państwowych każdoczesnego prawa kościelnego. Ustawa państwowa schodziła na dalszy plan, albowiem reprodukcja poszczególnych postanowień prawa kanonicznego miała jedynie charakter pouczenia. W tym układzie bezwzględnie obowiązujące przepisy państwowego prawa małżeńskiego regulowały tylko pewne zagadnienia. W pozostałym zakresie rozstrzygało prawo religijne, do którego odsyła bądź na które powołuje się ustawa państwowa. W konsekwencji regulacja prawa państwowego ogranicza się do określonych kwestii. Longchamps de Bérier wskazał te kwestie odrębnie dla wyznań objętych jurysdykcją cywilną sądów kościelnych oraz wyznań objętych jurysdykcją sądów powszechnych ${ }^{22}$.

W ocenie tego autora,

„wszelkie inne przepisy merytoryczne prawa z r. 1836 mają znaczenie bądź tylko informacyjne, o ile zgadzają się z każdoczesnym prawem kościelnym, bądź nie mają znaczenia, o ile są z niem sprzeczne, bez różnicy, czy sprzeczność ta istniała od początku, czy powstała skutkiem zmiany prawa wyznaniowego".

W świetle powyższego poglądu o stanie prawnym przesądzał aktualny kształt prawa kościelnego, a nie państwowego - prawa cywilnego. Rozwią-

możnaby wnosić, że tylko te przepisy, które wówczas obowiązywały i jako takie zostały do prawa z r. 1836 wciągnięte uzyskały moc obowiązująca, a wszelkie późniejsze zmiany tej mocy nie mają".

${ }^{22}$ R. Longchamps de Bérier, (w:) ibidem, s. 343-346, podaje, że prawo małżeńskie z 1836 r. zawiera regulacje:

1) co do wyznań, dla których obowiązuje jurysdykcja sądów państwowych, ale tylko o tyle, o ile przepisy państwowe bądź normują kwestie, prawem odnośnych wyznań nie rozstrzygnięte, bądź zawierają przepisy bezwzględnie obowiązujące;

2) co do innych wyznań tylko o tyle, o ile wprowadza pewne sankcje karne i cywilne stosowane przez sądy cywilne (np. skutki braku zezwoleń na małżeństwo, wymaganych przez prawo z 1836 r., a niewymaganych przez Kościół), oraz jako prawo małżeńskie międzywyznaniowe, tj. regulujące sprawę małżeństw mieszanych i skutki zmiany wyznania. 
zanie to trudno byłoby pogodzić z ukształtowaną już w XIX wieku koncepcją państwa prawnego, z której wynika idea suwerenności państwa. Idea ta wyrażała się $\mathrm{w}$ poglądzie o wyłącznej kompetencji państwa $\mathrm{w}$ przedmiocie stanowienia prawa. Państwo było zatem jedynym prawodawcą na swoim terytorium.

Prymat norm religijnych nad cywilnymi był obowiązującą zasadą w świetle orzecznictwa sądów kościelnych katolickich i prawosławnych. Tylko sądy konsystorskie ewangelickie orzekały ściśle według przepisów ustawy państwowej. Podkreślić jednak należy, że w przypadku wyznań ewangelickich ustawa ta nie odsyłała do regulacji kościelnych, kompleksowo normując małżeństwo osób należących do wyznań ewangelickich. W przypadku sądów wyznania katolickiego dominowała tendencja do stosowania przepisów kanonicznych, choćby nawet wbrew ustawie państwowej. Ponadto, pozycja polityczna tego wyznania w międzywojennej Polsce sprawiała, że biskupi katolicy czuli się całkowicie bezkarni. W konsekwencji naruszenia przepisów państwowego prawa międzywyznaniowego, do których dochodziło w sprawach o unieważnienie małżeństwa, nie skutkowały żadnymi sankcjami dla składu orzekającego. Bezkarność ta ujawniła się w całej rozciagłości w toku rozgrywającego się na początku niepodległości konfliktu pomiędzy Sądem Arcybiskupim Warszawskim a konsystorzami ewangelickimi w przedmiocie masowego unieważniania małżeństw zawartych w Kościele ewangelickim.

Odrębną kwestią było orzecznictwo konsystorzy prawosławnych. Przepisy prawa państwowego nie zawierały kompleksowej regulacji małżeństwa w tym wyznaniu. Sądy kościelne stosowały zatem prawo kanoniczne po części z obowiązku, po części z konieczności. Dopiero u schyłku II Rzeczypospolitej doszło do swego rodzaju kodyfikacji przepisów o małżeństwie prawosławnym w Statucie Konsystorzy Diecezjalnych, zatwierdzonym przez Ministra Wyznań Religijnych i Oświecenia Publicznego 6 V 1939 r. (MP Nr 136 z 16 VI 1939).

Prawo małżeńskie z 1836 r. było w okresie międzywojennym przedmiotem różnych ocen, często nie do końca słusznych. Oceny te były bezkrytycznie powielane w literaturze powojennej. W II Rzeczypospolitej prawo to uznawano za przejaw rosyjskiego absolutyzmu; traktowano zatem jak prawo obcego państwa narzucone narodowi polskiemu wbrew jego woli. H. Konic tak charakteryzował prawo małżeńskie Kongresówki:

„Z góry wszakże trzeba sobie uprzytomnić, że prawo z r. 1836 nie jest bynajmniej ustawą polska, przez naród polski w osobie swych przedstawicieli przygotowana. Jest to prawo bezwzględnie nam narzucone, na gruncie petersburskim zredagowane. Zapewne uczestniczyli w opracowywaniu projektu, jak widzieliśmy, niektórzy polacy, odwoływano się po opinię do Warszawy, zapytywano się o zdanie biskupów polskich, oraz komisję rządową sprawiedliwości, t.j. quasi ministerjum sprawiedli- 
wości, lecz bądź, co bądź w Petersburgu ułożono go definitywnie i tam też nadano mu kształty ostateczne. [...] Tkwiła tu dążność do unifikacji ustawodawstwa Królestwa Polskiego z ustawodawstwem rosyjskiem, a więc cel polityczny"23.

Prawa małżeńskiego z 1836 r. nie można jednak uznać za przejaw rosyjskiego dyktatu. Prawo to wprowadzone zostało na żądanie polskiego kleru katolickiego i cieszyło się jego aprobatą w stopniu nieporównywalnie większym aniżeli uchwalony przez sejm 11 lat wcześniej kodeks cywilny. W sprawie różnorodności norm prawnych stwierdzić należy, że i kodeks sejmowy przewidywał w art. 249 stosowanie ustaw religijnych małżonków w sprawach rozwodowych, co w praktyce uniemożliwiało katolikom rozwiązanie ich związku bez uprzedniej zmiany wyznania. Prawo małżeńskie jedynie poszło dalej w tym samym kierunku, ustanawiając poza różnorodnością norm, także jurysdykcje niektórych Kościołów w sprawach małżeńskich. Krok ten nie sytuuje prawa małżeńskiego w szeregu nowoczesnych ustaw europejskich tamtego okresu. Jurysdykcja kościelna w sprawach małżeńskich z pewnością nie stanowiła przejawu postępowej myśli prawnej XIX wieku. Po pierwszej wojnie światowej była już zupełnym anachronizmem. Jak trafnie podkreślał Bes,

,jednym z przeżytków szczątkowych dawnej epoki są przede wszystkim sądy konsystorskie, wyrokujące między osobami wyznań chrześcijańskich w nader ważnych sprawach rozwodowych, które we wszystkich krajach europejskich, nie wyłączając arcykatolickiej Hiszpanji, przekazane są już dzisiaj sądom świeckim"24.

Negatywna ocena jurysdykcji matrymonialnej sądów kościelnych z perspektywy historycznej nie może jednak mieć wpływu na obiektywną konieczność rozstrzygnięcia dylematu, który pojawił się na tle regulacji kodeksu cywilnego z 1825 r. Kodeks ten ustanowił bowiem obligatoryjne śluby religijne przy jednoczesnym utrzymaniu właściwości sądów cywilnych w sprawach małżeńskich. Niekonsekwencja ta stała się zarzewiem konfliktu, który władze państwowe musiały rozstrzygnąć w jedną lub drugą stronę. Charakterystyczne jest, że to właśnie H. Konic, pomimo negatywnej oceny przyjętych przez carat rozwiązań, sformułował pogląd o nieuchronności prawa mikołajewskiego. Autor ten uznał bowiem, że chociaż

„prawo z r. 1836 ogłoszono wbrew życzeniom reprezentacyi narodowej z r. 1818, 1825 i 1830, było ono koniecznością prawodawczą, logiczną konsekwencyją rozporządzeń kodeksowych z r. 1825. Skoro prawodawca uczynił z małżeństwa instytucyję religijną, skoro uznał, że nie może ona oprzeć się wyłącznie na gruncie

${ }^{23}$ H. Konic, Prawo matżeńskie..., s. 49.

${ }^{24}$ Bes, Z praktyki sqdu konsystorskiego, GSW Nr 4/1922 r., s. 32. 
cywilno-prawnym, to z konieczności musiał iść w ślad za głosami duchowieństwa i oddać jurysdykcję matrymonialną kościołowi" ${ }^{25}$.

Zaznaczyć jednak należy, że przyjęta w dekrecie mikołajewskim formuła regulacji małżeństwa nie była w realiach zaborczych całkowicie pozbawiona sensu. Ocena prawa małżeńskiego musi bowiem uwzględniać okres historyczny, w którym ono powstało i obowiązywało. Nie wszystkie bynajmniej instytucje prawa małżeńskiego należy ocenić ujemnie, zresztą nawet te, które na krytykę zasługują, nie miały w warunkach rozbiorowych wyraźnie negatywnego charakteru. W związku z powyższym odnieść się należy do krytyki lansowanej przez H. Świątkowskiego, który idąc śladami K. Lutostańskiego ${ }^{26}$, wysunął przeciw ustawie z $1836 \mathrm{r}$. dwa zarzuty natury ogólnej, mianowicie: 1) dążność do scementowania ustawodawstwa zaboru rosyjskiego z ówczesnym prawem rosyjskim oraz 2) zamiar rozbicia społeczeństwa polskiego na odrębne grupy narodowościowo-wyznaniowe ${ }^{27}$. Pierwszy z zarzutów nie podlega dyskusji, natomiast drugi jest błędny. Prawo z 1836 r. miało w warunkach rozbiorowych dokładnie odwrotny skutek - konsolidowało społeczność polską w obrębie własnego kręgu kulturowo-wyznaniowego. Brak własnej organizacji państwowej czynił kryterium przynależności państwowej dla identyfikacji narodowościowej Polaków całkowicie bezużytecznym. Natomiast podziały wyznaniowe przebiegały z reguły zgodnie z podziałami narodowościowymi. Poszczególne wyznania były wręcz swoistymi enklawami grupującymi ludność o określonym obliczu kulturowym i etnicznym. Ludność niemiecka była na ogół wyznania luterańskiego. Ludność ukraińska i białoruska wyznania prawosławnego i grecko-katolickiego. Ludność polska dominowała w wyznaniach: rzymsko-katolickim i częściowo kalwińskim. W tej sytuacji wyostrzenie podziałów wyznaniowych za pomocą ustawodawstwa małżeńskiego było, paradoksalnie, korzystne. Wyostrzało zarazem podziały narodowościowe. Mankamentem takiego rozwiązania było oczywiście utrwalenie podziałów wyznaniowych. Mankament ten dotyczył jednak w takim samym stopniu austriackiej powszechnej księgi ustaw cywilnych, co prawa mikołajewskiego. Stanowi on bowiem ogólny koszt przyjęcia konfesyjnego systemu prawa małżeńskiego.

W literaturze tak powojennej, jak i międzywojennej dominuje negatywna ocena dekretu mikołajewskiego, eksponująca zwłaszcza jego zaborowy rodowód. Niemniej, stosunek do prawa małżeńskiego z 1836 r. nie był wolny od paradoksów. Było to niewątpliwie prawo zadekretowane przez obcego monarchę, aczkolwiek akceptowane przez pokaźną część polskiego społeczeństwa, zwłaszcza tę o konserwatywnym obliczu i silnym przywiązaniu do katolicy-

${ }^{25}$ H. Konic, Dzieje..., s. 140.

${ }^{26}$ K. Lutostański, Zasady projektu prawa małżeńskiego, Warszawa 1931, s. 5.

${ }^{27}$ H. Świątkowski, Wyznaniowe prawo państwowe, Warszawa 1962, s. 72. 
zmu, na co wskazuje choćby jego zagorzała obrona w dwudziestoleciu międzywojennym. Lecz prawo z 1836 r. spotkało się również z krytyką katolickich komentatorów. J. Brzeziński uważał, że jego założenia dotyczące małżeństw katolickich oraz małżeństw mieszanych polegają na wadliwym pojmowaniu prawideł kościelnego prawa małżeńskiego ${ }^{28}$. Z przeciwległych pozycji krytykowano omawianą ustawę w Przewodniku dla urzędów stanu cywilnego.

Stwierdzono mianowicie:

„Wyznaniowy charakter prawa o małżeństwie, które zgodnie z zasadą kanoniczną nie dopuszcza rozwiązania związku małżeńskiego, zawartego w kościele katolickim, uznając jednocześnie rozwody małżeństw niekatolickich, jest przyczyną dość częstych zmian wyznania ze strony osób wyznających religję katolicką, w celu uzyskania rozwodu. Różnorodność norm prawnych dla poszczególnych grup obywateli jednego państwa jest absurdem z punktu widzenia prawno-państwowego. Normy prawne w państwie konstytucyjnym powinny być jednakie dla wszystkich obywateli. Mikołajewskie prawo o małżeństwie, wyrosłe w atmosferze niewoli politycznej i na gruncie nacisku wyznaniowego i religijnego, jest przeżytkiem absolutyzmu rosyjskiego, tradycjom Rzeczpospolitej całkowicie obcym i rażąco sprzecznym z zasadami konstytucji. Wyzwolenie narodu z krępujących jego rozwój więzów, narzuconych ongi przez absolutystyczne rządy carskie, jest nieodzowną koniecznością państwową"29.

Należy również wskazać na okoliczność sytuującą dekret mikołajewski w rzędzie specyficznych rozwiązań ustawodawczych ostatnich kilkuset lat. Od reformacji datuje się stała tendencja do przełamania monopolu Kościoła rzymskokatolickiego w sferze stosunków małżeńskich. Jednakże prawdziwy przełom w tym względzie przyniósł dopiero okres Oświecenia, a w szczególności Rewolucji Francuskiej. W rezultacie sukcesów militarnych Napoleona na ziemiach polskich wprowadzono nowe świeckie prawo francuskie. Małżeństwo, jak niegdyś w państwie rzymskim, stało się na powrót czysto laicką instytucją prawną. Prawo małżeńskie z 1836 r. stanowi natomiast ciekawy przykład powstrzymania tendencji sekularyzacyjnych w tym obszarze regulacji stosunków społecznych. W świetle preambuły motyw ten uznać należy za zasadniczy dla ustawodawcy. W preambule czytamy:

„Sprawy małżeńskie, co do głównego przedmiotu swego, za dawney Polski, ulegały rozpoznaniu władzy duchowney; następnie ten starożytny porządek zupełney uległ zmianie; małżeństwo uznano za umowę cywilną, i zarazem tak zawarcie onego, iako też rozwiązanie, uczyniono zawisłem od władz cywilnych. W roku

${ }^{28}$ Zob. rec. Józefa Brzezińskiego, „Czasopismo Prawne i Ekonomiczne”(V) 1904, s. 229 i nast.

${ }^{29}$ A. Rżewski, I. Szwarcman, Przewodnik dla urzędów stanu cywilnego, wyd. II, Łódź 1923, s. 134 . 
1825 sprostowanem zostało to zboczenie od dawnych zasad, lecz sprostowanie nastapiło w części, o ile okoliczności ówczesne dozwalały; stanowienie zaś o rozwiązaniu onego, przy władzy cywilney pozostawiono".

Widzimy więc, że narodowy kodeks cywilny nie spełnił oczekiwań ustawodawcy z 1836 r., gdyż nie przełamywał w pełni skutków sekularyzacji małżeństwa w postaci jurysdykcji państwa w sprawach małżeńskich.

Jednakże w 1836 r. nie zdecydowano się na całkowite usunięcie wpływu władzy państwowej na stosunki małżeńskie. W preambule dekretu podkreślono, że stosunki majątkowe wynikające $\mathrm{z}$ małżeństwa pozostaną w gestii sądów cywilnych. W konsekwencji tylko sprawy z zakresu osobowego prawa małżeńskiego przekazano sądom kościelnym. „Przyiąwszy takie prawidło wypadało oprzeć na niem tryb działania iedney i drugiey władzy: władzy duchowney, zgodnie z prawami kanonicznemi; władzy cywilney, zgodnie z ogółem praw cywilnych". W tym ustępie preambuły sformułowano naczelną zasadę dekretu mikołajewskiego - podzielność kompetencji, czyli właściwość każdej z wymienionych władz w swoim zakresie - kościelnej względem religijnej strony małżeństwa, a cywilnej względem strony majątkowej. Zasada ta zaciążyła na historycznej ocenie ustawy mikołajewskiej. Stanowiła także swego rodzaju wyznacznik charakteryzujący unormowania prawa z 1836 r. oraz determinujący ścisły związek orzecznictwa kościelnego z orzecznictwem państwowym w majątkowych sprawach małżeńskich.

\section{THE ORIGIN AND NATURE OF MATRIMONIAL LAW OF 1836}

\section{S u m m a r y}

The paper presents events that had preceded the work on the drafting of matrimonial law for the territory of Poland established at the Vienna Congress (1815) as an autonomous unit under the name the Kingdom of Poland, formerly under the occupation of the Russian Empire. The existing Napoleon Code that applied to that territory provided for a lay character of matrimony and as such was opposed by the Roman Catholic church. As a result, the dispute concerning the nature of the state matrimonial law that continued between 1818 and 1830 ended in the implementation in 1836 of a law of a mixed character that combined elements of the lay and well as religious approaches. That law had remained in force until 1945.

The complexity of matrimonial law of 1836 was a consequence of its provisions based of religious principles of individual religious denominations. Hence, interpretation and application of that law, already difficult because of its dual character, was fur- 
ther hindered by the unclear relation of that law to the underlying it religious laws, and particularly, the importance of the Catholic canon law provisions in civil law relationships. The judicial decisions of the interwar period (1918-1945) did not provide any uniform interpretation of that issue. However, two basic views regarding the reception of religious law in the state's matrimonial law were formulated. In one, pursuant to the adopted formula of incorporation of religious law in the matrimonial law enacted by the state, only those religious norms that were included in the state law constituted the basis for effective solutions and decisions. According to the other view, religious law attained a state law value by the very fact that the matrimonial law of 1836 had referred to religious laws and regulations.

After the end of World War II, matrimonial law in its previous shape was practically neglected. Since 1989, following the change in the political regime, a religious concept of matrimony has been promoted, but nothing than mere postulates in that matter have been so far proposed.

\section{PROBLÈME DE LA CRÉATION ET DU CARACTÈRE DU DROIT MATRIMONIAL DE 1836}

\section{R é s u m é}

Dans la présente dissertation, nous traitons des événements précédant les travaux sur le projet de la loi matrimoniale pour le territoire autonome de l'Empire russe, constitué par l'acte du Congrès de Vienne en 1815 d'une partie des territoires de l'ancienne Pologne. Le territoire est appelé le Royaume de Pologne avec le Code Napoléon en vigueur, ce dernier prévoyant un caractère laïque du mariage. C'est d'ailleurs la raison pour laquelle l'Église catholique romaine lutte contre le code. Par conséquent, dans les années 1818-1830, naît un conflit quant à la forme que devrait revêtir le droit matrimonial public. Le désaccord en la matière au sein de la Diète (chambre basse du parlement) provoque en 1836 la mise en place du droit à caractère mixte, profane et confessionnel. Il reste en vigueur jusqu'à la fin de 1945.

Le caractère complexe du droit matrimonial de 1836 résulte du fait que ses dispositions se basent sur des réglementations religieuses de différentes communautés confessionnelles. Le manque de clarté dans le rapport entre ce droit et les droits religieux constituant son origine n'a fait qu'augmenter les difficultés de son interprétation et son application. Le problème concerne notamment la question de l'importance de la législation canonique catholique dans les rapports de droit civil, prévus par la loi de 1836. La doctrine de l'entre-deux-guerres n'a pas de position claire en la matière. Deux idées portant sur la réception du droit religieux dans le droit matrimonial public ont été formulées. Dans le premier cas, est admise la formule d'incorporation du droit religieux dans le droit public, à l'issue de laquelle seules les normes religieuses incluses dans la loi publique étaient la base des décisions efficaces sur le plan national. Dans 
le second cas, il est admis que le droit matrimonial de 1836 fait appel à la réglementation religieuse, ce qui veut dire qu'il renvoie en général au droit religieux lequel, de ce fait, prend la valeur du droit public.

Le droit matrimonial de 1836 tombe dans l'oubli après la Seconde Guerre mondiale. Cependant, après les transformations politiques de 1989, le concept de mariage confessionnel est promu en Pologne, les idées s'étant arrêtées au stade de postulats à date. 